\title{
PELATIHAN DAN PENGEMBANGAN SUMBER DAYA MANUSIA \\ DENGAN KERAJINAN KAIN PERCA GUNA MENINGKATKAN PENDAPATAN IBU-IBU RUMAH TANGGA DAN GURU-GURU TK RA AL QUR'ANIYAH KELURAHAN PONDOK CABE ILIR
}

\author{
Sari Karmiyati ${ }^{1}$, Neneng Khoiriah ${ }^{2}$, Dewi Ningsih ${ }^{3}$, Abdullah $^{4}$, Aan Purnama ${ }^{5}$ \\ Universitas Pamulang \\ Email: dosen02489@unpam.ac.id
}

\begin{abstract}
Community Service Activities carried out by a team of lecturers in the undergraduate management study program at Pamulang University (UNPAM) in 2020 are community service activities that focus on training and development of patchwork for mothers and TK RA AL-Qur'aniyah teachers. This activity begins with an explanation of how to use rags or recycled fabrics so that they have a useful value and can be used as income if they are sold by mothers, then continue with the practice of making beautiful brooches out of patchwork. It was found that 95\% of the mothers and teachers who attended were all able to make and create patchwork brooches. With this activity, it is hoped that it can be used as a solution to financial problems because the products produced from these patches have a use value and a selling value.
\end{abstract}

Keywords: Training, Create Bross, Pacthwork.

\begin{abstract}
Abstrak
Kegiatan Pengabdian Kepada Masyarakat yang dilakukan oleh tim dosen program studi manajemen S1 Universitas Pamulang (UNPAM) tahun 2020 merupakan kegiatan pengabdian kepada masyarakat yang menitikberatkan pada Pelatihan dan Pengembangan dari kain perca untuk ibu-ibu dan guruguru TK RA AL - Qur'aniyah. Kegiatan ini diawali dengan pemaparan bagaimana cara memanfaatkan kain perca atau daur ulang sehingga mempunyai nilai guna dan bisa menjadi pendapatan jika dijual oleh ibu-ibu kemudian dilanjutkan dengan praktek cara membuat bros cantik dari kain perca. Diperoleh hasil 95\% ibu-ibu dan guru-guru yang hadir semua bisa membuat dan mengkreasikan bros dari kain perca. Dengan adanya kegiatan ini diharapkan dapat dijadikan solusi dalam masalah keuangan karena produk yang dihasilkan dari kain perca tersebut memiliki nilai guna dan nilai jual.
\end{abstract}

Kata Kunci: Pelatihan, Mengkreasikan Bross, Kain Perca. 


\section{A. PENDAhULUAN}

Kain perca merupakan limbah tekstil atau potongan kain sisa dari proses penjahitan yang sudah tidak terpakai. Kain perca dapat dijadikan kerajinan suatu produk yang sangat berguna, dengan kreatifitas kita dapat memanfaatkan kain perca menjadi produk yang memiliki nilai ekonomi. Proses dan pengadaan kain perca tidak terlalu sulit sehingga memudahkan untuk dilakukan oleh ibu-ibu rumah tangga. Ibu-ibu rumah tangga merupakan lingkungan sumber daya manusia yang sangat memungkinkan untuk diberikan pelatihan pemanfaatan kain perca sehingga dapat menambah pendapatan ibu-ibu rumah tangga, begitu juga dengan guru-guru TK, diharapkan dengan pelatihan kain perca orang tua murid/wali murid dan guru-guru TK dapat diterapkan untuk diri sendiri guna meningkatkan pendapatan dan dapat memberikan pengetahuan mengenai kegunaan kain perca.

Peran serta ibu rumah tangga saat ini layak diperhitungkan dan perlu dikembangkan dalam mensejahterakan keluarga.Seorang ibu juga sebaiknya bisa mandiri, tidak hanya tergantung pada suami.Seorang ibu yang mandiri adalah pribadi yang secara proaktif mengambil tindakan-tindakan tertentu untuk mendukung dan membina rumah tangganya. Perempuan wirausaha juga dinilai lebih bertanggung jawab dan profesional dalam mengelola keuangan.Pemerintah maupun perbankan pun telah mendukung para wirausahawan dan wirausahawati melalui pemberian akses keuangan.Akses tersebut diharapkan dapat memberi kesempatan bagi para wirausaha dalam mengembangkan usahanya. Kaum perempuan merupakan kelompok yang proaktif dan dalam situasi tertentu serta berani mengambil inisiatif terutama menghadapi situasi sosial ekonomi yang berkaitan langsung dengan peningkatan kesejahteraan dan kualitas hidup keluarganya..Tentunya para perempuan ini tidak hanya ingin menjadi Ibu rumah tangga biasa saja yang hanya mengerjakan pekerjaan rumah pada umumnya. Akan tetapi selain bisa menjaga keutuhan rumah tangga juga tetap bisa produktif di dalam rumah.

Permasalahan yang dihadapi adalah belum ada pemberdayaan ibu-ibu rumah tangga dalam meningkatkan pendapatan rumah tangga, kurangnya pengetahuan pemanfaatan limbah kain perca. Tujuannya untuk meningkatkan keterampilan kreasi dan inovasi kerajinan tangan dari kain perca dalam peningkatan ekonomi keluarga. Kain perca juga dapat dijadikan usaha yang bergerak dibidang industri rumah tangga, sehingga dapat meningkatkan kesejahteraan hidup. Dalam pemanfaatan kain perca kami memilih pembuatan bros, bros dapat dibuat sebagai pelengkap fashion. Hal ini cukup menjanjikan karena dapat menjadi potensi usaha dengan biaya hemat memanfaatkan limbah kain perca bisa melakukan bisnis sendiri maupun kelompok.

Usaha kerajinan tangan tidak harus mengeluarkan modal yang besar, namun memanfaatkan limbah rumah tangga atau dengan bahan seadanya sudah bisa memulai usaha kerajinan tangan ini. Contohnya saja kerajinan tangan bros. Untuk memulai usaha kerjainan tangan bros dari kain perca ini kita hanya membutuhkan bahan utama kain perca, jarum, benang, lem, gunting, pisau, semet dan manik-manik untuk beberapa tambahan, sehingga usaha ini cocok untuk ibu-ibu rumah tangga untuk mendatangkan penghasilan tambahan. Ketika melihat tumpukan sampah berupa kain perca disalah satu warga yang berprofesi sebagai penjahit, muncul ide untuk memanfaatkannya untuk menjadi sesuatu yang bermanfaat.Hal ini timbul dari keprihatinan sehubungan dengan pemanasan global yang diakibatkan oleh salah satunya adalah pengelolaan sampah/waste disposal, sampah berupa kain sintetis adalah termasuk sampah anorganik yang paling sulit didaur ulang oleh bumi kita.

Dengan memanfaatkannya menjadi sesuatu yang bisa digunakan kembali akan memberi dampak yang sangat baik bagi bumi yaitu mengurangi efek pemanasan global. Berawal dari ketrampilan memanfaatkan kain perca untuk dijadikan berbagai kerajinan tangan, pelaksana 
mampu menghasilkan kerajinan tangan dengan bahan utama kain perca.Menyadari bahwa ketrampilan ini memiliki banyak manfaat dari segi ekonomi, maka pelaksana ingin berbagi ketrampilan ini kepada ibu-ibu rumah tangga.

Kerajinan perca sudah ada sejak zaman Mesir Kuno dan Cina Kuno, yaitu sekitar 5000 tahun yang lalu.Pada masa pertengahan abad, kain perca digunakan untuk melapisi baju perang para prajurit yang terbuat dari baja.Seiring dengan bergulirnya waktu, masa abad XI hingga XIII orang-orang Eropa yang berpindah ke Amerika sudah mulai mengenal tehnik kerajinan perca ini.Didukung cuaca yang sangat dingin, penduduk Eropa tidak mendapat tempat yang memadai maka mereka menggunakan sisa-sia bahan kain untuk ditempelkan pada dinding. Selain itu mereka juga membuat untuk kebutuhan rumah tangga.Seperti selimut, baju dan yang lainnya.Berkembangnya kemajuan jaman, kreasi dan motif -motif baru mulai bermunculan.Pada akhir abad ke delapan belas hingga abad sembilan belas para wanita mulai menemukan pola kombinasi dan bahan kain yang tepat untuk hiasan.Sejak itulah seni kerajinan perca mulai tersebar ke seluruh penjuru dunia yang dibawa oleh para pengembara dan musafir.

Kerajinan kain perca saat ini sudah menjadi salah satu kerajinan yang paling dikagumi dan diminati oleh banyak orang Indonesia, bahkan juga di seluruh dunia.Awalnya kerajinan ini merupakan salah satu kerajinan tradisional.Namun, sekarang kerajinan ini malah menjadi salah satu tren baru di dunia kerajinan. Kain perca merupakan sisa kain dari proses penjahitan. Sepintas kain sisa ini adalah kain yang tidak memiliki manfaat, tapi sebenarnya sisa kain ini dapat dimanfaatkan menjadi suatu produk yang berguna.Daripada terbuang menjadi sampah lebih baik digunakan sebagai barang yang lebih berguna.

Kain perca merupakan limbah anorganik yang membutuhkan waktu lama untuk terurai, untuk menaggulangi permasalahan limbah khususnya pada limbah kain perca, dan untuk pengembangan sumberdaya manusia menjadi masyarakat yang mandiri secara ekonomi, maka perlu adanya pelatihan kreatifitas pada ibu-ibu rumah tangga dan guru-guru TK Al Qur'aniyah Pondok Cabe Ilir dengan memanfaatkan kain perca menjadi suatu karya yang bernilai artistik, ramah ingkungan, berkearifan lokal sekaligus ekonomis. Metode yang digunakan adalah pengarahan dan praktek pembuatan kerajinan dengan kain perca. Dengan demikian diharapkan dapat mengurangi limbah kain perca dan dapat meningkatkan pendapatan ibi-ibu rumah tangga dan guru-guru TK Al Qur'aniyah Pondok Benda Ilir.

Memanfaatkan kain perca sebagai bahan baku utama pembuatan aneka kerajinan ternyata bisa menjadi salah satu peluang bisnis yang sangat menguntungkan. Dari kain sisa jahitan yang awalnya tidak bernilai, bisa dikreasikan menjadi berbagai macam produk kerajinan yang memiliki fungsi dan harga jual cukup tinggi.

\section{B. METODE PELAKSANAAN}

Metode kegiatan ini berupa pelatihan ketrampilan kepada ibu-ibu rumah tangga dan guru-guru TK AL Qur'aniyah tentang bagaimana cara membuat aksesoris dari kain perca.

Berikut ini adalah tahapan pelatihan yang dilakukan :

1. Tahap Persiapan

Tahap persiapan yang dilakukan meliputi :

Survey awal, pada tahap ini dilakukan survei ke lokasi Jl. Kubis IV, Kelurahan Pondok Cabe Ilir

a. Pemantapan dan penentuan lokasi dan sasaran. Setelah survei maka ditentukan lokasi pelaksanaan dan sasaran kegiatan.

b. Penyusunan bahan/materi pelatihan ketrampilan yang meliputi : Slide, makalah dan bahan-bahan pembuatan aksesoris perca. 


\section{Tahap Pelaksanaan Pelatihan}

Tahap ini akan memberikan penjelasan tentang bagaimana cara membuat ketrampilan dari kain perca, sesi ini menitikberatkan pada pengarahan atau pemaparan dan contoh-contoh ketrampilan dari kain perca.

Untuk melaksanakan kegiatan tersebut, maka digunakan beberapa metode pelatihan, yaitu:

a. Metode Ceramah

Metode ceramah dipilih untuk memberikan penjelasan tentang ketrampilan dari kain perca.

b. Metode Tanya Jawab

Metode Tanya jawab ini dipilih karena sangat penting bagi para peserta pelatihan ketrampilan bagi ibu-ibu rumah tangga dan guru-guru dalam menggali pengetahuan sebanyak-banyaknya tentang ketrampilan dari kain perca.

c. Metode Simulasi/praktek

Metode simulasi/praktek ini diberikan kepada para peserta pelatihan dalam memberikan kesempatan untuk mempraktekkan ketrampilan dari kain perca.

Tujuan dilakukan praktek pembuatan bros dari kain perca ini adalah meningkatnya kompetensi para peserta pelatihan dalam membuat bros dari kain perca. Selain itu peserta pelatihan juga akan memiliki kepercayaan diri karena memiliki keterampilan membuat bros dari kain perca. Menumbuhkan kepercayaan diri ini sangat penting agar peserta pelatihan antusias mengikuti kegiatan pelatihan ini

\section{HASIL DAN PEMBAHASAN}

Kerajinan kain perca merupakan salah satu kerajinan yang memanfaatkan limbah kain sisa jahit, dari limbah kain perca dapat digunakan untuk kerajinan pembuatan bross.Caranya adalah dengan memotong-motong beragam kain sisa menjadi berbagai bentuk, kemudian dibuat pola dan menjahitnya kembali sesuai bentuk yang diinginkan. Kegiatan pelatihan pembuatan boss dari bahan kain perca ini dilakukan di kelurahan pondok cabe ilir ditujukan pada ibu-ibu rumah tangga dan TK Al Qur'aniah, kegiatan PKM ini dilakukan bertujuan meningkatkan kreatifitas dan produktivitas kepada masyrakat selain itu dapat meningkatkan tingkat ekonomi masyarakat pondok cabe ilir.

Alat dan Bahan yang digunakan :

1. Gunting

2. Benang dan Jarum Jahit

3. Jarum Pentul

4. Peniti Bros

5. Kain Perca

6. Lem

7. Penggaris

8. Manik-manik atau bisa diganti dengan kancing baju Langkah-langkah cara membuat Playdough :

1. Menyiapkan alat dan bahan

2. Masukan benang kedalam jarum

3. Siapkan kain yang hendak dijahit

4. Bentuk motif yang akan dibuat

5. Ketika motif kegiatan sudah dibuat maka mulailah menjahit.

6. Setelah terjahit berikan asesoris atau pernak-pernik untuk memperindah bros yang sudah di jahit

7. Setelah itu berikan lem untuk merekatkan peniti bros. 
Hasil dan luaran yang dicapai dalam pelaksanaan kegiatan pengabdian kepada masyarakat ini adalah sebagai berikut:

1. Kegiatan Pengabdian kepada Masyarakat ini diharapkan mampu memberikan pengetahuan, wawasan peluang usaha dan gambaran secara menyeluruh bahwa bahan limbah dari kain perca dapat mempunyai nilai ekonomis dan bermanfaat khususnya bagi para ibu rumah tangga untuk mengisi waktu luang dapat membantu dan menambah masukan bagi ekonomi keluarga.

2. Memberikan kesadaran kepada masyarakat khususnya para ibu rumah tangga untuk mempersiapkan diri secara mental, fisik dengan bermodal ketrampilan yang dimiliki dapat menumbuhkan minat untuk berwirausaha.

3. Menumbuhkan sikap kreatif, inovatif dan mampu mengelola hasil yang diperolehnya, yang periode selanjutnya mulai berbisnis berskala kecil kepada masyarakat khususnya untuk para ibu rumah tangga.

4. Memberikan ilmu pengetahuan dan pemahaman tentang kewirausahaan khususnya pemanfaatan peluang untuk berbisnis dan gambaran bagaimana pengelolaan hasilnya.

5. Dengan kegiatan pelatihan ini, secara langsung membantu pemerintah dalam mengurangi pengangguran dengan memberikan bekal kepada masyarakat khususnya para ibu rumah tangga untuk memanfaatkan waktu luang dengan mempergunakan bahan limbah menjadi bernilai ekonomis untuk dijual dan dapat membantu ekonomi keluarga agar lebih sejahtera dalam kehidupannya.

Kegiatan pengabdian kepada masyarakat yang dilaksanakan adalah berjudul "Pelatihan dan Pengembangan Sumber Daya Manusia Dengan Kerajinan Kain Perca Guna Meningkatkan Pendapatan Ibu-ibu Rumah Tangga dan Guru-guru TK RA Al Qurianiyah Kelurahan Pondok Cabe Ilir ". Hal ini diharapkan bermanfaat bagi masyarakat khususnya bagi para ibu rumah tangga dan Guru-guru TK RA Al Qurianiyah Kelurahan Pondok Cabe Ilir. Sedangkan harapan dari pelaksanaan pengabdian masyarakat ini adalah untuk mengurangi pengangguran dengan memberikan wawasan, pelatihan dan ketrampilan kepada masyarakat khususnya bagi para ibu rumah tangga, pada prinsipnya jika ada peluang dan waktu luang dapat dipergunakan untuk kegiatan yang berguna dan bernilai ekonomis untuk membantu perekonomian keluarga.

Hasil dari pemberian pelatihan ini dapat memberikan tambahan bekal ilmu pengetahuan yang dapat dipertimbangkan untuk bermanfaat bagi masyarakat khususnya bagi para ibu rumah tangga. Dalam pelaksanaan pelatihan khususnya dalam pembuatan karangan bunga (buket) dan perhiasan bros bunga kecil diberikan contoh dan dipraktikan, dibimbing dengan langkah-langkah secara berurutan satu persatu agar dapat memberikan gambaran secara nyata kepada para ibu-ibu. Hal itu bertujuan memberikan kesempatan untuk memperdalam dan memberikan semangat serta menggali minat kepada para ibu-ibu rumah tangga untuk belajar dan memanfaatkan waktu luang untuk berwirausaha sesuai minat.

\section{KESIMPULAN DAN SARAN}

\section{Kesimpulan}

Pelatihan yang dilakukan di wilahah POndok Cabe, tepatnya TK RA Al Qur'aniyah sudah dilakukan dengan baik dan dapat diterima dengan peserta Pengabdian Kepada Masyarakat (PKM) dengan baik pula.

Pelatihan dan pengembangan tentang mendaur ulang kain perca yang dilakukan di RA.Al Qur'aniyah dapat dijadikan solusi dalam masalah keuangan karena produk yang dihasilkan dari kain perca tersebut memiliki nilai guna dan nilai jual. 
2. Saran

Dalam Pengabdian Kepada Masyarakat tentang Pelatihan dan Pengembangan SUmber Daya Manusia dengan Kerajinan dari Kain Perca yang telah dilakukan diharapkan agar peserta mampu untuk mengembangkan model bros yang telah dipraktikan dalam kegiatan PKM tersebut.

\section{Ucapan Terima Kasih}

Rasa syukur dan suka cita kamu haturkan kepada segenap pihak yang telah mensukseskan kegiatan PKM dengan judul "Pelatihan dan Pengembangan Sumber Daya Manusia Dengan Kerajinan Kain Perca Guna Meningkatkan Pendapatan Ibu-ibu Rumah Tangga dan Guru-Guru TK Al Qur'aniyah kel. Pondok Cabe Ilir" kepada:

1. Rektor Dr. H. Dayat Hidayat, M.M, Rektor Universitas Pamulang, Tangerang Selatan Banten.

2. Dr. Ali Maddinsyah, S.E., M.M., selaku Ketua LPPM Universitas Pamulang, Tangerang Selatan - Banten.

3. Dr. Kasmad, S.E., M.,M., selaku Ketua Program Studi Manajemen S1 Universitas Pamulang, Tangerang Selatan - Banten.

4. Dr. Udin Ahidin, S.E., M.M., C.M.A, Selaku Wakil Program Studi Manajemen S1 Universitas Pamulang, Tangerang Selatan - Banten.

5. Drs. Waluyo Jati, M.M., Selaku Sekretaris Program Studi Manajemen S1 Universitas Pamulang Tangerang Selatan - Banten.

6. Nurhaya, S.Pd, selaku Kepala TK RA Al Qur'aniyah Pondok Cabe Ilir Kecamatan Pamulang, Tangerang Selatan - Banten.

7. Staff-staff TK RA Al Qur'aniyah Pondok Cabe Ilir Kecamatan Pamulang, Tangerang Selatan - Banten.

8. Mahasiswa Universitas Pamulang yang juga ikut berkontribusi terhadap kelancaran kegiatan PKM.

\section{DAFTAR PUSTAKA}

Dumilah, R., Sunarto, A., Solihin, D., \& Maulida, H. (2020). Pelatihan Pemanfaatan Media Sosial Untuk Promosi Usaha Atau Bisnis Bagi Siswa. DEDIKASI PKM, 1(1), 26-33.

Widodo, E. S. (2015), Manajemen Pengembangan Sumber Daya Manusia.Yogyakarta: Pustaka Pelajar.

Frida, F. (2014). Kreasi Kain Perca. Demedia Pustaka: Jakarta.

Hasibuan, M. S.P. (2016), Manajemen Sumber Daya Manusia. Edisi Revisi. Jakarta : PT. Bumi AKsara.

Mardiana, S., Supriyatna, W., Hasanah, Y. M., Zakaria., \& Indirasari, I. (2010). Optimalisasi Anggaran Keuangan Di Masa Pandemi Pada Desa Cicalengka Kabupaten Pagedangan Tangerang. DEDIKASI PKM. 1(3).

Qurbani, D., Mardiana, S., \& Nugroho, R. D. (2020). Meningkatkan Minat Dan Potensi Generasi Milenial Khususnya Siswa-Siswi Smk Darussalam Untuk Memulai Bisnis Online Dengan Sistem Dropship. DEDIKASI PKM. 1 (3).

Rastianah Nina. (2015). Aneka Kriya Limbah Produk. Yrama Widya: Bandung. 
Rivai, Veithzal dan Sagala, Ella Jauvani. (2011), Manajemen Sumber Daya Manusia untuk Perusahaan dari Teori ke Praktik.Jakarta : PT. Raja Grafindo

Rizkiana. Pemanfaatan Kain Perca Batik yang Melimpah dan Terabaikan sebagai Bahan Pembuatan BrossPetik di Desa Paweden, Pekalongan. Diakses 2 Mei 2015.

Roni Salinding. (2011). Analisis Pengaruh Pelatihan terhadap Produktivitas Kerja Karyawan pada PT. ERAJAYA. Skripsi.

Shofyatun A. Rahman. (2010), Pemanfaatan Kain Perca. Palu: Tadulako University Press.

Soeprihatno, Jhon. (2010). Penilaian Kinerja dan Pengembangan Karyawan Edisi Pertama, Cetakan Kelima BPFE.Yogyakarta.

Solihin, D., Susanto, N., Setiawan, R., Ahyani, \& Darmadi. (2020). PENERAPAN STRATEGI PEMASARAN SEBAGAI UPAYA MENINGKATKAN USAHA KECIL DAN MENENGAH WARGA DI KELURAHAN PANINGGILAN UTARA CILEDUG. ABDI LAKSANA, 1(3), 351-355.

Solihin, D., Prasetiyani, D., Sari, A. R., Sugiarti, E., \& Sunardi, D. (2020). PEMANFAATAN BOTOL BEKAS SEBAGAI PENYARING AIR BERSIH SEDERHANA BAGI WARGA DESA CICALENGKA KECAMATAN PAGEDANGAN KABUPATEN TANGERANG. DEDIKASI PKM, 1(3), 98-102.

Susilo, Karya. (2015). Pemanfaatan Limbah Kain Perca Untuk Pembuatan Furniture. ITB. Diakses 2 Mei 2015.

Sutrisno, Edi. (2009). Manajemen Sumber Daya Manusia Edisi Pertama. Jakarta : Kencana Prenada Media Group.

Ustania, Putri dkk. (2010). Inspirasi Souvenir. Tiara Aksa: Surabaya.

Yuliati Ida. (2010). Inspirasi dari Daur Ulang. Tiara Aksara: Surabaya. 